\title{
PENERAPAN PRINSIP 5C TERHADAP TINGKAT NON PERFORMING FINANCING (NPF)
}

\author{
Nanik Eprianti \\ Universitas Islam Bandung \\ Jalan Taman sari No. 24-26, Jawa Barat, Indonesia, 40116 \\ nanikeprianti@unisba.ac.id
}

\begin{abstract}
Abstrak
Pembiayaan salah satu produk yang banyak diminati msayarakat. Dalam meminimalisir kredit bermasalah, tahapan analisis kredit harus menerapkan prinsip $5 \mathrm{C}$ secara maksimal. Metode yg digunakan ialah deskriptif pendekatan kualitatif. Sumber data primer yaitu diambil dari annual report dan data sekunder yaitu buku, jurnal dan data yang mendukung dari bank. Hasil analisisperbankan yang ingin menekan tingkat NPF harus memperhatikan prinsip 5C dan menganalisa kredit harus mengutamakan kualitas bukan kuantitas. Selain itu terdapat pilar yang mendukung analisa seperti tiga pilar kelayakan yang menjadi dasar utama dari analisa kelayakan pemberian kredit meliputi :1)Kredibilitas manajemen 2)Kemampuan membayar kembali pembiayaan.3)Agunan dan 5 (Lima) regulator dalam mengurangi risiko kredit diantaranya:1)Otoritas Pemberian Pinjaman, 2) Jenis Kredit dan Distribusi Berdasarkan Kategori yang sesuai kebutuhan dan kemampuan calon nasabah, 3) Proses Penilaian diterapkan sesuai ketentuan prinsip proses pembiayaan, 4) Harga Kredit, 5) Penentuan Maturitas/Jatuh Tempo dilakukan untuk meringankan calon nasabah mengembalikan pinjaman ke bank.
\end{abstract}

Kata Kunci : Pembiayaan (Kredit),Non PerfomingFinacing

\begin{abstract}
Financing is one product that is in great demand on public. In minimizing problem loans, the stages of credit analysis must apply the principle of $5 \mathrm{C}$ to the maximum. The research method used is descriptive qualitative approach. Sources of data obtained from primary data is taken from the annual report and secondary data, namely books, journals and supporting data from the bank. The results of banking analysis that want to reduce the NPF level must pay attention to the $5 \mathrm{C}$ principle and analyze credit must prioritize quality not quantity. In addition, there are pillars that support analysis such as the three feasibility pillars which are the main basis of the feasibility analysis of lending including: 1) Management credibility 2) Ability to repay financing.3) Collateral and 5 (Five) regulators in reducing credit risk include: 1) Loan Provisioning Authority, 2) Types of Credit and Distribution Based on the category according to the needs and abilities of prospective customers, 3) The Assessment Process is applied in accordance with the principles of the financing process, 4) Credit Prices, 5) Determination of maturity to alleviate prospective borrowers to the bank. Keyword :Financing (Credit), Non PerfomingFinancing
\end{abstract}

\section{PENDAHULUAN}

Sejalan dengan perkembangan

ekonomi, kebutuhan masyarakat terhadap jasa-jasa lembaga keuangan juga meningkat baik dari segi kuantitas maupun dari segi kualitas. Lembaga keuangan disini meliputi lembaga keuangan bank dan non bank, meskipun dalam perekonomian lembaga keuangan perbankan yang lebih mendominasi.

Perkembangan perbankan syariah di Indonesia diawali dengan berdirinya Bank 
Muamalat Indonesia pada tahun 1991. Pada mulanya perbankan syariah belum mendapat perhatian yang optimal dari pemerintah, hal ini terlihat pada Undang Undang No 27 tahun 1992 yang belum menjelaskan adanya landasan hukum operasional perbankan syariah. Namun, setelah adanya undang-undang baru yaitu, Undang-Undang No. 10 tahun 1998 yang menjelaskan adanya dua system perbankan yaitu perbankan sistem bagi hasil dan sistem konvensional maka bank syariah semakin berkembang dan mulai dikenal oleh seluruh lapisan masyarakat.

Selaku regulator, BankIndonesia memberikan dukungan dalam mendorong perkembangan perbankan. Halini dilandasi oleh keyakinan bahwa perbankan akan membawa 'maslahat' bagi peningkatan ekonomi dan pemerataan kesejahteraan masyarakat.Perkembangan perbankan dapat dilihat dari meningkatkannya jumlah bank yang ada, serta minat masyarakat menggunakan produk perbankan, seperti produk tabungan, deposito, gadai , jasa dan pembiayaan.

Pembiayaan meruapakan salah satu produk yang banyak diminati msayarakat baik pengusaha maupun pegawai negeri sipil. Pembiayaan yang ditawarkan perbankan banyak ragamnya seperti kredit rumah, kredit usaha, kredit konsumsi, kredit modal kerja, kredit investasi dan lain-lain.

Pembiayaan atau kredit adalah penyerahan barang, jasa, atau uang dari satu pihak atas dasar kepercayaan kepada pihak lain dengan perjanjian pengembalian kembali serta waktu yang telah disepakati oleh kedua belah pihak. (Veitzhal Rivai. 2007). Dan Untuk mengurangi atau membatasi risiko kredit menurut (Greuning \& Bratanovic, 2011) terdapat 5 (Lima) regulator diantaranya 1)Otoritas Pemberian Pinjaman, 2)Jenis Kredit dan Distribusi Berdasarkan Kategori, 3)Proses Penilaian, 4)Harga

Kredit, 6)Maturitas/Jatuh Tempo.

Namun dilihat dari tingkat non perfoming financing perbankan saat ini cukup signifikan, dimana Rasio pembiayaan bermasalah (non performing finance) industri perbankan syariah masih relatif tinggi. Berdasarkan data Otoritas Jasa Keuangan (OJK), NPF perbankan syariah turun menjadi $4,7 \%$ dibandingkan periode yang sama tahun lalu sebesar $4,89 \%$. Sementara itu, perbankan konvensional sendiri, rasio kredit bermasalahnya (non performing loan) mencapai 3,05\%.

Dalam penelitian (Astrini \& dkk, 2014)bahwa semakin besar jumlah kredit yang disalurkan, maka akan memberikan 
konsekuensi semakin besarnya risiko yang harus ditanggung oleh pihak bank. Non Perfoming Financing dapat terjadi karena pada saat analisis kredit, penerapan prinsip $5 \mathrm{C}$ belum maksimal dimana penilaian dalam capacity calon nasabah masih ada yang memberikan bukti gaji tidak sesuai yang sebenarnya, serta dari promosi pembiayaan, terdapat pemberian kredit tanpa jaminan dan atau ada jaminan tetapi nilai jaminan lebih rendah dari pinjaman, maka ketika mengalami kesulitan ekonomi nasabah kesulitan untuk membayar kembali pinjaman ke bank, hal ini dapat menimbulkan kredit bermasalah.

Beberapa hal yang tidak diterapkan dalam analisis kredit menimbulkan pembiayaan bermasalah, karena tujuan analisis kreditadalah menilai mutu permintaan kredit yang diajukan, sehingga dapat menekan terjadinya risiko kredit, (Sutojo, 2008). Maka rumusan masalah yang akan di teliti ialah bagaimanapenerapananalisis pembiayaan (kredit) di perbanakan?, dan bagaimana solusi untuk meninimalisirnon perfoming financing ?. Dimana tujuan penelitian yang akan dicapai untuk mengetahui proses pembiayaan dalam perbankan sesuai dengan prinsip evaluasi kredit sertamemahami solusi meninimalisirnon perfoming financing.
Dalampenelitian ini menggunakan metode penelitian deskriptif analisis dengan pendekatan kualitatif(Jogiyanto, 2010). Analisis dilakukan dengan cara mengumpulkan data-data sesuai dengan yang sebenarnya kemudian data-data tersebut disusun, diolah dan dianalisis untuk dapat memberikan gambaran mengenai masalah yang ada. Hal ini dilakukan untuk memberikan informasi dan gambaran secara sistematis, faktual, dan akurat mengenai fakta-fakta mengenai objek analisis. Sumber data yang dijadikan rujukan dalam penelitian ini terdiri atas : Data primer yaitu annual report bank dan data sekunder yaitu buku, jurnal serta datadata yang ada dari bank pembiayaan rakyat syariah.

Berdasarkan penelitian terdahulu yaitu (Eprianti, 2015) meneliti pengaruh kredit investasi, good corporate governance, $\mathrm{LDRdan} \mathrm{CAR}$ terhadap risiko kredit bank.Hasil penelitian diperoleh secara simultan terdapat pengaruh signifikankredit investasi, good corporate governance, loan to deposit ratio dan capital adequancy ratio terhadap risiko kredit bank. Tetapi secara parsial mendapatkan hasil yang bervariasi yaitu menunjukkan bahwa kredit investasi mempunyai pengaruh positif signifikan terhadap risiko kredit bank, dan good corporate governance mempunyai 
pengaruh negatif signifikan terhadap risiko kredit bank. Loan to deposit ratio mempunyai pengaruh negatif tidak signifikan terhadap risiko kredit bank, sedangkan untuk capital adequancy ratio mempunyai pengaruh positif tidak signifikan terhadap risiko kredit bank.

(Kartika, 2013) meneliti pengaruh suku unga KPR, LDR, NPL dan DPK terhadap pertumbuhan kredit kepemilikan rumah di Indonesia. Dengan menggunakan uji asumsi klasik serta uji hipotesis yaitu fixed effext model, sehingga hasil penelitian menunjukan bahwa tidak terdapat pengaruh suku bunga, LDR dan NPL terhadap pertumbuhan KPR namun terdapat pengaruh antara CAR dengan pertumbuhan KPR.Serta (Astrini \& dkk, 2014) tentang pengaruh CAR, LDR dan bank size terhadap NPL. Teknik analisis yang dgubakan dalam penelitian ini ialah pendekatan kuantitatif yang menggunakan anlisis regresi berganda, sehingga hasil penelitian yang didapat bahwa terdapat pengaruh negatif CAR terhadap NPL, kemudian terdapat pengaruh positif LDR terhadap NPL serta terdapat pengaruh bank size terhadap NPL.

\section{PEMBAHASAN}

\section{A. Kredit}

Kredit berasal dari kata credere atau creditum. Credere dari bahasa Yunani artinya kepercayaan, sementara creditumdari bahasa latin artinya kepercayaan akan kebenaran. Sehingga kata tersebut memiliki implikasi bahwa setiap kegiatan perkreditan harus dilandasi kepercayaan. (Taswan, 2010)

Kredit adalah penyerahan barang, jasa, atau uang dari satu pihak atas dasar kepercayaan kepada pihak lain dengan perjanjian pengembalian kembali serta waktu yang telah disepakati oleh kedua belah pihak. (Eprianti, 2015).

Kredit ialah bentuk interaksi berdasarkan kepercayaan.(Akhmad \& Haryadi, 2006)

$\begin{array}{lrr}\text { Kredit } & \text { berarti } & \text { memperoleh } \\ \text { kepercayaan atas dasar } & \text { kepercayaan } \\ \text { kepada } & \text { seseorang } & \text { yang } \\ \text { memerlukannya.(Hariyani, } & \text { 2010). } & \text { Maka } \\ \text { diberikan uang atau jasa } & \text { dengan } & \text { syarat } \\ \text { membayar kembali dengan jangka } & \text { waktu } \\ \text { tertentu yang diperjanjikan. }\end{array}$

\section{B. Syarat Pengajuan Kredit:}

Dalam pengajuan kredit pada suatu bank syariah maupun bank konvensional, ada beberapa syarat yang harus dipenuhi oleh calon nasabah sebagai berikut a)warga negara indonesia, b)foto copy ktp, c)memiliki rekening tabungan bank yang bersangkutan, d)mengisi formulir pengajuan permohonan pinjaman, e)foto copy kk, f)surat nikah, g)npwp, h)slip gaji, 
i)izin usaha (pengusaha), j)izin praktek untuk professional, k)foto copy rekening tabungan, dan 1)dokumen peminjaman (seperti shm dlam properti).(Eprianti, 2015)

\section{Unsur Kredit}

Kredit diberikan atas dasar kepercayaan sehingga pemberian kredit adalah pemberian kepercayaan. Hal ini diyakini dapat mengembalikan kredit sesuai dengan waktu dan syarat-syarat yang sudah disepakati. Berdasarkan hal tersebut, unsur-unsur dalam perkreditan sebagai berikut; adanya dua pihak, adanya kepercayaan pemberian kredit kepada penerima kredit, adanya persetujuan atau kesepakatan, adanya penyerahan barang, jasa atau uang, adanya unsur waktu, adanya unsur risiko dan adanya unsur bunga sebagai kompensasi, (Eprianti, 2015).

\section{Jenis Kredit}

Berbagai jenis kredit baik berdasarkan golongan, berdasarkan jangka waktu, berdasarkan keperluan dan sebagainya. Berikut adalah jenis-jenis kredit diantaranya :

1. Berdasarkan jangka waktu yaitu terdapat jangka pendek, jangka menengah dan jangka panjang.

2. Berdasarkan sifat penggunaan terdiri dari kredit konsumtif dan kredit komersial.
3. Berdasarkan keperluan terdiri dari kredit consumer, kredit ritel dan kredit wholesale.

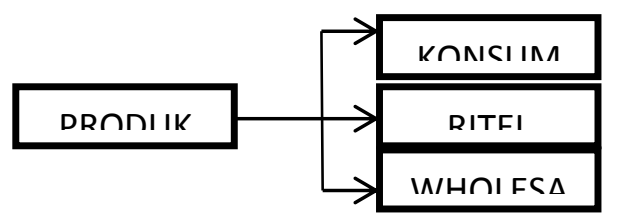

\section{Gambar : JenisKredit,}

(Akhmad \& Haryadi, 2006)

\section{E. Tujuan Penggunaan Kredit}

Menurut (Taswan, 2010)tujuan pemberian kredit minimal akan memberikan manfaat bagi :

1. Bank ialah dapat digunakan sebagai instrument bank dalam memelihara likuiditas, solvabilitas dan rentabilitas, kemudian dapat menjadi pendorong peningkatan penjualan produk bank yang lain dan kredit diharapkan dapat menjadi sumber uatama pendapatan bank.

2. Debitur ialah diharapkan dapat digunakan untuk memperlancar usaha dan selanjutnya meningkatkan gairah usaha sehingga terjadi kontinuitas perusahaan.

3. Masyarakat ialah mampu menggerakan perekonomian masyarakat, peningkatan kegiatan ekonomi masyarakat akan mampu menyerap tenaga kerja dan pada 
Nanik Eprianti, Penerapan Prinsip 5 C..

waktunya akan dapat

dijelaskan sebagai berikut:(Tamin,

mensejahterakan masyarakat.

2012)

\section{F. Fungsi Kredit}

Fungsi kredit perbankan dalam kehidupan perekonomian dan perdagangan menurut (Suyatno \& dkk, 2007) antara lain sebagai berikut :

1. Kredit pada hakikatnya dapat meningkatkan daya guna uang

2. Kredit dapat meningkatkan peredaran dan lalu-lintas uang

3. Kredit dapat pula meningkatkan daya guna dan peredaran uang

4. Kredit sebagai salah satu alat stabilitas ekonomi

5. Kredit dapat meningkatkan kegairahan berusaha

6. Kredit dapat meningkatkan pemerataan pendapatan

7. Kredit sebagai alat meningkatkan hubungan internasional

\section{G. Prinsip Evaluasi Kredit}

Agar kredit yang diberikan berkualitas maka harus dilakukan evaluasi sehingga risiko kredit dapat diantisipasi sejak awal. Dalam mengevaluasi kredit, bank melakukan penilaian terhadap calon debitur dengan prinsip 5C yaitu keyakinan bank terhadap aspek character, capital, capacity, collateral dan condition of economic, yang dapat 
psemasaran dari hasil usaha debitur yang dibiayai dengan kredit bank.

\section{H. Prinsip Pemantauan Kredit}

Kredit yang telah diberikan harus dipantau secara aktif dan konsisten, meliputi pemantauan terhadap usaha debitur dan pemenuhan persyaratan kredit. Dengan pemantauan, bank dapat segera mengetahui gejala-gejala penurunan kualitas kredit sehingga bank dapat segera melakukan langkah-langkah awal pencegahan dan perbaikan untuk menghindari terjadinya penurunan kualitas kredit debitur.(Ningsi, Azib, \& Eprianti, 2019)

\section{Risiko Kredit}

Menurut (Greuning \& Bratanovic, 2011)risiko kredit atau risiko rekanan adalah ketika debitur atau penerbit instrument keuangan, baik individu, perusahaan maupun Negara tidak akan membayar kembali kas pokok dan lainnya yang berhubungan dengan investasi sesuai dengan ketentuan yang ditetapkan dalam perjanjian kredit.

Menurut Ikatan Bankir Indonesia dan Lembaga Sertifikat Profesi Perbankan (2013) risiko kredit ialah risiko akibat kegagalan debitur dan/atau pihak lain dalam memenuhi kewajiban kepada bank.

\section{J. Faktor-Faktor Penyebab Kredit Macet}

Faktor-faktor penyebab kredit macet adalahsebagaiberikut :

a.Faktoreksternal bank

1) Adanya maksud tidak baik dari para debitur yang diragukan.

2) Adanyakesulitanataukegagalandalam proses likuiditasdariperjanjiankredit yang telah disepakati antara debitur dengan bank.

3) Kondisi manajemen dan lingkungan usaha debitur.

4) Musibah (misalnya : kebakaran, bencana alam) atau kegagalan usaha.

b.Faktor internal bank

1) Kurang adanya pengetahuan dan keterampilan para pengelola kredit.

2) Tidak adanya kebijakan perkreditan pada bank yang bersangkutan.

3) Pemberian danpengawasankredit yang dilakukanoleh bank menyimpangdariprosedur yang telahditetapkan, danlemahnya organisasi dan manajemen dari bank yang bersangkutan. (Claudya $\& \mathrm{dkk}, 2014)$.

\section{K. Kebijakan Manajemen Untuk Mengurangi Risiko Kredit}

Sebuah kebijakan kredit harus berisi garis beras dari ruang lingkup dan alokasi fasilitas kredit bank serta sebagai portofolio kredit dikelola, yaitu bagaimana pinjaman berasal, dinilai, diawasi dan 
Nanik Eprianti, Penerapan Prinsip 5 C..

dikumpulkan. Untuk mengurangi atau membatasi risiko kredit menurut (Greuning \& Bratanovic, 2011) terdapat 5 (Lima) regulator diantaranya:

1. Otoritas Pemberian Pinjaman

2. Jenis Kredit dan Distribusi Berdasarkan Kategori

3. Proses Penilaian

4. Harga Kredit

5. Maturitas/Jatuh Tempo

\section{Tahapan Yang Harus Dilalui Pada} Setiap Pembiayaan Yang

Disalurkan Kepada Nasabah

Penerimaan Fasilitas Oleh Bank

Syariah, Diantaranya:

1. Tahap Analisis pembiayaan

2. Tahap Dokumentasi pembiayaan

3. Tahap Pengawasan dan pengamanan pembiayaan

4. Tahap penyelamatan dan penagihan pembiayan.

\section{Analisa Kelayakan Pemberian Pembiayaan}

Bank dalam memberikan kredit dituntut harus dapat meminimalisir potensi-potensi terjadinya kredit macet di kemudian hari. Oleh sebab itu, analisa kelayakan kredit yang merupakan tahapan pertama dari proses perkreditan harus dilakukan dengan tepat, cermat dan benar berdasarkan ketentuan-ketentuan yang berlaku dalam perkreditan sehingga peluang terjadinya kerugian bagi bank yang ditimbulkan dari kredit macet dapat diantisipasi dari sejak dini. Berikut tiga pilar kelayakan yang menjadi dasar utama dari analisa kelayakan pemberian kredit meliputi :

1. Kredibilitas manajemen yang ditunjang oleh Sub Pilar yaitu :

a. Kejujuran, iktikadbaik key person daripenerimap embiayaan .

b. Kemampuan mengelola usaha key person.

2. Kemampuan membayar kembali pembiayaan yang ditunjang oleh Sub Pilar yaitu :

a. Hasil prestrasi usaha yang ditentukan oleh keberhasilan dalam pemasaran dan teknis produksi.

b. Likuiditas yang ditentukan oleh keberhasilan dalam pengelolaan keuangan antara cash inflow dan cash outflow.

3. Agunan yang diserahkan yang ditunjang oleh Sub Pilar yaitu :

a. Harga jual kembali agunan jika terpaksa dijual. 
b. Kelengkapan, integritasdokumen legal agunan.

Pilar Pertama dan Kedua disebut first way out, dimana kelayakan usaha nasabah berpijak, Pilar Ketiga disebut second way out yang merupakan cover atas risiko kegagalan yang terjadi pada first way out. Menurut (IBI \& LSPP, 2013) secara lebih luas risiko kredit mengandung 3 (tiga) komponen, yaitu :

1. Peluang gagal bayar (probability of default), yaitu ketidak mampuan debitur dalam memenuhi kewajibannya kepada bank.

2. Eksposur kredit (exposure credit), yaitu berkaitan dengan potensi jumlah kerugian jika debitur gagal bayar.

3. Tingkat pemulihan (recovery rate), yaitu tingkat pengembalian kredit yang telah gagal bayar sebagai upaya pemulihan kinerja bank.

\section{N. Menilai Kapasitas Manajemen \\ Risiko Kredit}

Ketika melaksanakan tugasnya atas nama deposan atau pemegang saham, dewan direksi harus memastikan bahwa fungsi pinjaman sebuah bank harus memenuhi 3 (Tiga) tujuan dasar seperti :

1. Kredit harus diberikan atas pertimbangan yang sehat dan dapat tertagih
2. Dana harus diinvestasikan secara menguntungkan untuk kepentingan pemegang saham dan perlindungan deposan.

3. Kebutuhan kredit sah para agen ekonomi dan rumah tangga harus terpenuhi.

\section{O. Kolektibilitas Kredit}

Risiko pemberian kredit yang paling tidak disukai bank adalah terjadi kredit bermasalah. Hal ini umumnya terjadi Karena egagalan pihak debitur memenuhi kewajibannya untuk membayar angsuran pokok kredit beserta bunganya seperti telah dituangkan sebelumya dalam perjanjian kredit. Menurut (Leon \& Ericson, 2007) sehubung dengan adanya risiko kredit bermasalah tersebut, maka bank membagi peringkat kreditnya kedalam beberapa kategori kolektibilitas sebagaimana yang ditentukan oleh Bank Indonesia. Adapun kategori kolektibilitas kredit tersebut sebagai berikut :

1. Kredit lancar, yaitu kredit yang tidak mengalami penundaan pengembalian pokok pinjaman maupun bunganya.

2. Kredit dalam perhatian khusus, yaitu kredit yang mengalami penundaan pembayaran pokok dan bunganta selama 1 sampai 2 bulan dari waktu yang dijanjikan.

3. Kredit kurang lancar, yaitu kredit yang pengembalian pokok dan 
bunganya telah mengalami penundaan selama 3 bulan dari waktu yang teah dijanjikan.

4. Kredit diragukan, yaitu kredit yang pengembalian pokok dan bunganya telah mengalami penundaan selama 6 bulan atau 2 kali dari jadwal yang telah dijanjikan.

5. Kredit macet (NPL), yaitu kredit yang pengembalian pokok pinjaman dan pembayaran bunganya telah mengalami penundaan lebih dari satu tahun sejak jatuh tempo menurut jadwal yang telah dijanjikan.

\section{P. Dampak Kredit Bermasalah}

Berikut ini beberapa dampak jika kredit yang disalurkan oleh bank bermasalah, antara lain: 1)Laba/Rugi bank menurun Penurunan Laba tersebut diakibatkan adanya penurunan pendapatan bunga kredit. 2)Bad Debt Ratio menjadi lebih besar Rasio aktiva produktif menjadi lebih rendah. 3)Biaya pencadangan penghapusan kredit meningkat Bank perlu membentuk pencadangan atas kredit bermasalah yang lebih besar. Biaya pencadangan penghapusan kredit akan berpengaruh pada penurunan keuntungan bank. 4)Return On Assets (ROA)dan
Return On Equity (ROE) menurun Penurunan laba akan memiliki dampak pada penurunan Return On Assets, karena Return turun, maka ROA dan ROE akan menurun.(Ismail, 2010)

\section{Q. Bagaimana Penerapan Analisis Pembiayaan (Kredit) Di Perbankan?}

Perbankan syariah maupun konvensional secara keseluruhan menerapkan dan melakukan Proses pembiayaan cukup baik, tetapi dalam menerapkanPrinsip 5C dalam proses pembiayaan masih ada yang diabaikan, diantaranya :

1. Character: diilihat dari karaker calon nasabah pembiayaan yang mengajukan memiliki karakter jujur, beriktikad baik dan tidak menyulitkan bank dikemudian hari.

2. Capacity: biasanya penilaian bank atas kemampuan calon nasabah pembiayaan dilihat dari bukti gaji atau laporan penghasilan usaha, namun terdapat beberapa nasabah yang memberikan bukti gaji atau laporan keuangan yang tidak sesuai dengan yang sebenarnya.

3. Capital, penilaian bank ini dilakukan untuk mengetahui pengeluaran dan 
pemasukan calon nasabah pembiayaan, hal ini bertujuan untuk melihat apakah posisi keuangan calon nasabah secara keseluruhan, termasuk aliran kas calon nasabah, baik untuk masa lalu maupun proyeksi pada masa yang akan datang, mampu dalam menunjang pembiayaan proyek atau usaha calon nasabah yang bersangkutan.

4. Collateral, penilaian bank terhadap jaminan yang dimiliki oleh calon nasabah pembiayaan, dimana nilai jaminan harus lebih tinggi dari pinjaman. Namun dilihat dari promosi pembiayaan, terdapat pemberian kredit tanpa jaminan hal ini terjadi karena tujuan pihak tertentu untuk mempermudah proses pencairan. Hal inibertolakbelakangdenganhasilpenelit ian(Chadijah, 2017)diamanaKredit macet merupakan salah satu kondisi yang tidak dapat dihindari. Apabila ternyata kredit tersebut sudah tidak dapat diselamatkan lagi maka bank dapat melakukan eksekusi objek hak tanggungan. Jika di awalkreditsudahtidakadajaminanmaka risikokredittidakdapatdihindari.

(Chadijah,

2017)Kemudianpenelitianini di perkuatdenganhasilpenelitian(Saparid a, 2016), yang mengatakanbahwakebijakan yang dibuat oleh lembaga dilalaikan, dimanajikapersetujuan kredit hanya berdasarkan atas nama baik dari peminjam. Pihak lembaga tidak melakukan penilaian kredit yang cukupketat seperti kurang menerapkan prinsip-prinsip perkreditan yang sehat dalam permohonan kredit sebagaimana mestinya seperti prinsip lima C yaitu; (1) Character, (2) Capital, (3) Capacity, (4) Condition, dan (5) Collateral. Pihak lembaga hanya menilai dari sisi capacityatau daya bayar anggota, tanpa ada jaminan. Dengan tidak adanya jaminan ini juga menjadi penyebab kredit macet.

5. Condition of Economic, penilaian bank bagi calon nasabah pembiayaan untuk usaha ini dilakukan agar mengantisipasi pendapatan usaha calon nasabah kedepan apakah masih mampu dalam membayar angsuran pinjaman dalam kondisi apapun.

Selaras dengan hasil penelitian (Fauzi, 2018)yang menyimpulkan bahwa kredit macet terhadap kinerja di dapat nilai 0,358 yang artinya jika kredit macet megalami kenaikan satu rupiah, maka pengaruh terhadap kinerja akan meningkat sebesar $35,8 \%$. Koefisien bernilai positif yang artinya antara kredit macet dan 
kinerja memiliki hubungan yang positif, serta kenaikan pada jumlah kredit macet akan mengakibatkan pengaruh terhadap kinerja.

\section{R. Bagaimana solusi untuk meninimalisirnon perfoming financing?}

Bank dalam memberikan kredit dituntut harus dapat meminimalisir potensi-potensi terjadinya kredit macet di kemudian hari. Oleh sebab itu, analisa kelayakan kredit yang merupakan tahapan pertama dari proses perkreditan harus dilakukan dengan tepat, cermat dan benar berdasarkan ketentuan-ketentuan yang berlaku dalam proses pembiayaan sehingga peluang terjadinya kerugian bagi bank yang ditimbulkan dari kredit macet dapat diantisipasi dari sejak dini.Berikut tiga pilar kelayakan yang menjadi dasar utama dari analisa kelayakan pemberian kredit meliputi :

1. Kredibilitas manajemen yang ditunjang oleh Sub Pilar yaitu :

a. Kejujuran, iktikadbaik key person daripenerimapembiayaan .

b. Kemampuan mengelola usaha key person.

2. Kemampuan membayar kembali pembiayaan yang ditunjang oleh Sub Pilar yaitu: a. Hasil prestrasi usaha yang ditentukan oleh keberhasilan dalam pemasaran dan teknis produksi.

b. Likuiditas yang ditentukan oleh keberhasilan dalam pengelolaan keuangan antara cash inflow dan cash outflow.

3. Agunan yang diserahkan yang ditunjang oleh Sub Pilar yaitu :

a. Harga jual kembali agunan jika terpaksa dijual.

b. Kelengkapan, integritasdokumen legal agunan.

Dan menurut (Greuning \& Bratanovic, 2011) terdapat 5 (Lima) regulator dalam mengurangi risiko kredit diantaranya:

a) Otoritas Pemberian Pinjaman

b) Jenis Kredit dan Distribusi Berdasarkan Kategori yang sesuai kebutuhan dan kemampuan calon nasabah

c) Proses Penilaian diterapkan sesuai ketentuan prinsip proses pembiayaan

d) Harga Kredit

e) Penentuan Maturitas/Jatuh Tempo dilakukan untuk meringankan calon nasabah mengembalikan pinjaman ke bank.

Dalam penelitia(Bayuaji, 2017)memberikan solusi mengatakan bahwa Pelaksanaan Penyelesaian Kredit 
Macet yang diikat dengan Hak Tanggungan yaitu dengan melakukan tindakan restrukturisasi pinjaman, pengalihan fasilitas dan pelunasan sebagian atau seluruhnya. Kemudian dalam penelitiannya, (Apriyanto, 2014)memberikan solusi yaitu dalam melakukan penyelesaian kredit bermasalah lebih mengutamakan penyelesaian melalui jalur non litigasi, hal ini dikarenakan penyelesaian kredit bermasalah melalui jalur non litigasi lebih menguntungkan bagi debitor maupun kreditor. Penyelesaian kredit bermasalah melalui jalur non litigasi adalah penyelesaian yang saling menguntungkan (win-win solution). Langkah-langkah untuk mencapai penyelesaian kredit bermasalahyaitumelalui cara, konsultasi, negoisasi, mediasi, konsiliasi.

\section{SIMPULAN}

Berdasarkan dari hasil analilis, maka simpulan nya adalah :

Pertama perbankan yang ingin menekan tingkat Non Perfoming Finance harus memperhatikan ptinsip $5 \mathrm{C}$ dan mengaanlisa kredit harus mengutamakan kualitas bukan kuantitas. Perbankan syariah maupun konvensional secara keseluruhan menerapkan dan melakukan Proses pembiayaan cukup baik tetapi dalam menerapkan 5C terkadang masih diabaikan, hal ini terlihat dari kelengkapan berkas yang dibutuhkan bank masih belum lengkap, kemudian terdapat beberapa nasabah yang memberikan bukti gaji atau laporan keuangan yang tidak sesuai dengan yang sebenarnya, serta terdapat pemberian kredit tanpa jaminan hal ini terjadi karena tujuan pihak tertentu untuk mempermudah proses pencairan. KeduaBank dalam memberikan kredit dituntut harus dapat meminimalisir potensi-potensi terjadinya kredit macet di kemudian hari. Oleh sebab itu, analisa kelayakan kredit yang merupakan tahapan pertama dari proses perkreditan harus dilakukan dengan tepat, cermat dan benar berdasarkan ketentuan-ketentuan yang berlaku dalam perkreditan sehingga peluang terjadinya kerugian bagi bank yang ditimbulkan dari kredit macet dapat diantisipasi dari sejak dini. Berikut tiga pilar kelayakan yang menjadi dasar utama dari analisa kelayakan pemberian kredit meliputi :1)Kredibilitas manajemen yang ditunjang oleh Sub Pilar yaitu : Kejujuran, iktikad baik key person dari penerima pembiayaan. Kemampuan mengelola usaha key person. 2)Kemampuan membayar kembali pembiayaan yang ditunjang oleh Sub Pilar yaitu: Hasil prestrasi usaha yang ditentukan oleh keberhasilan dalam pemasaran dan teknis produksi. Likuiditas yang ditentukan oleh keberhasilan dalam pengelolaan keuangan 
Nanik Eprianti, Penerapan Prinsip 5 C..

antara cash

inflow dan cash

outflow.3)Agunan yang diserahkan yang ditunjang oleh Sub Pilar yaitu : Harga jual kembali agunan jika terpaksa dijual. Kelengkapan, integritasdokumen legal agunan.Menurut Hennie Van Greuning dan Sonja Bracovic Bratanovic terdapat 5 (Lima) regulator dalam mengurangi risiko kredit diantaranya:1)Otoritas Pemberian Pinjaman, 2) Jenis Kredit dan Distribusi Berdasarkan Kategori yang sesuai kebutuhan dan kemampuan calon nasabah, 3) Proses Penilaian diterapkan sesuai ketentuan prinsip proses pembiayaan, 4) Harga Kredit, 5) Penentuan Maturitas/Jatuh Tempo dilakukan untuk meringankan calon nasabah mengembalikan pinjaman ke bank.

Sebagaimana yang diuraikan diatas penulis pada bagian ini mencoba memberikan saran-saran sebagai masukan, untuk bahan pertimbangan bagi pihak Bank Syariah maupun Konvensional untuk memberikan pembiayaan. Adapun saransaran tersebut adalah sebagai berikut:pertama, Pihak Bank harus lebih efektif dan efisien dalam menganalisis calon nasabah pembiayaan (kredit) dengan menerapkan prinsip 5C serta pilar-pilar dan regulator yang menjadi patokan analisis.Kedua, Pihak Bank diharapkan harus melihat peluang kebutuhan masyarakat dalam memenuhi target bank, bukan dengan mempermudah analsis pembiayaan untuk pencapaian target tertentu yang dapat menimbulkan pembiayaan bermasalah. Ketiga, Mengadakan pelatihan untuk meningkatkan wawasan dan pengetahuan sumber daya manusia bank dalam analsis kredit dan menejemen risiko.

\section{DaftarPustaka}

Akhmad, \& Haryadi, A. (2006). Aplikasi Excel Dalam Pengambilan Keputusan Memilih Kredit. Jakarta: PT. Elex Media Komputindo.

Apriyanto, Y. B. (2014). Penyelesaian Kredit Bermasalah Pada Bank DKI Jakarta Cab. Solo Melalui Jalur Non Litigasi. Universitas Atmajaya Yogyakarta .

Astrini, S., \& dkk. (2014). PengaruhCAR, LDR Dan Bank Size Terhadap NPL Pada Lembaga Perbankan Yang Terdaftar di BEI. Universitas Pendidikan Ganesha. E-Journal .

Bayuaji, G. (2017). Pelaksanaan Penyelesaian Kredit Macet Yang Diikat Dengan Hak tanggungan Di PT. Bank Tabungan Pensiunan Nasional Mitra usaha rakyat Cab.Tegal. Jurnal Akta, Vol.4 No.1.

Chadijah, R. L. (2017). Penyelesaian Kredit Bermasalah Melalui Parate Eksekusi. Kanun Jurnal Ilmu Hukum 
Claudya, F., \& dkk. (2014). Analisis Kredit Macet. Jurnal Administrasi Bisnis .

Eprianti, N. (2015). Pengaruh Kredit Investasi, GCG, LDR dan CAR terhadap Risiko Kredit Bank. Tesis Universitas Padjadjaran .

Fauzi, A. (2018). Kredit Macet, NPL dan Pengaruhnya Terhadap Kinerja Perusahaan Pada Perusahaan Pembiayaan. Umabis : Jurnal Manajemen \& Bisnis , PP 27-36.

Greuning, H. V., \& Bratanovic, S. B. (2011). Analisis Risiko Perbankan. Jakarta: Salemba Empat.

Hariyani, I. (2010). Restruksi \& Penghapusan Kredit Macet. Jakarta: PT. Elex Media Komputindo Kompas Gramedia.

IBI, \& LSPP. (2013). Memahami Bisnis Bank. Jakarta Utara: PT. Gramedia Pustaka Utama.

Ismail. (2010). Manajemen Perbankan : Dari Teori Menuju Aplikasi. Jakarta: Kencana.

Jogiyanto. (2010). Metode Penelitian Bisnis. Yogyakarta: Anggota IKAPI.

Kartika, D. P. (2013). Pengaruh Suku Bunga KPR, LDR, NPL Dan DPK terhadap Pertumbuhan KPR di Indonesia. Skripsi Universitas Padjadjaran .

Leon, B., \& Ericson, S. (2007). Manajemen Aktiva Pasiva Bank Non Devisa. Jakarta: Grasindo.

Ningsi, A. R., Azib, \& Eprianti, N. (2019). Pengaruh Kepatuhan Syariah (Sharia
Compliance) Terhadap Operasional Risiko Pembiayaan Pada Perbankan syariah. Seminar Peneliatian Sivitas Akademik Unisba (SPESIA). Bandung: Prosiding Hukum Ekonomi Syariah.

Saparida. (2016). Analisis Kredit Macet Pada Koperasi Karyawan Tirta Dharma Khatulistiwa Kota Pontianak. Skripsi Universitas Tanjungpura Pontianak .

Sutojo, S. (2008). Menangani Kredit Bermasalah. Jakarta: PT. Damar Mulia Pustaka.

Suyatno, T., \& dkk. (2007). Dasar-dasar Perkreditan. Jakarta: PT. Gramedia Pustaka Utama.

Tamin, N. (2012). Kiat Menghindari Kredit Macet. Jakarta: PT. Dian Rakyat.

Taswan. (2010). Manajemen Perbankan. Yogyakarta: UPP STIM YKPN Yogyakarta. 